\title{
THE DEVELOPMENT OF INTERMODAL FREIGHT TRANSPORT IN POLAND FROM 2007 TO 2016: BARRIERS AND OPPORTUNITIES TO ITS FURTHER DEVELOPMENT
}

\author{
Dominika Mońka ${ }^{1}$, Robyn Pyne ${ }^{2}$, Dimitrios Paraskevadakis ${ }^{3}$, Alan Bury ${ }^{4}$ \\ ${ }_{1,2,3,4}$ Liverpool John Moores University, Faculty of Engineering and Technology, Maritime and Mechanical \\ Engineering, UK
}

Received 2 October 2020; accepted 20 December 2020

\begin{abstract}
International transport has grown dynamically in Poland since it becomes a European Union (EU) member. This being the case, it is now, more than ever, important to identify the approaches that are most suitable for delivering sustainable freight transport to the nation. Intermodal options appear to be the most appropriate for this task. This study examines the development of intermodal freight transport in Poland from 2007 to 2016. It considers the barriers overcome and that remain to be overcome as well as identifying opportunities for further development. Initially, secondary data sourced from the Główny Urząd Statystyczny, Urząd Transportu Kolejowego and Eurostat databases, was utilised to explore the situation. This was then reinforced by primary data collection, in the form of a survey, the aim of which being to validate the reviewed literature and the findings of the derived from the database data with the subjective perspective of the respondents. It was found that although the prevalence of intermodal transport has an upward trend in Poland its uptake remains significantly lower than in other EU member states. The major issue inhibiting the development of intermodal transport in Poland is the condition of the nation's infrastructure. This is accompanied by an element of concern for the external costs generated by intermodal carriers. However, Poland's participation in a range of EU funded projects that support the modernisation of its ageing infrastructure has been, and remains, a major driving force behind the ongoing development of the intermodal transportation of freight within the country.
\end{abstract}

Keywords: intermodal transport, Poland, railway, maritime, inland waterways, container transport, EU projects, transport infrastructure.

\section{Introduction}

Increasing levels of international trade have led to an increase in demand for global freight transport solutions. If freight transport continues to grow in accordance with European Commission (2019) predictions, by 2050 it will have increased by as much as $80 \%$ from today's figures. Intermodal transport is a crucial element of delivering an efficient and sustainable increase to freight transportation that, whilst on the one hand, responds to the growing demand for freight transport, on the other, considers its impact upon the environment. Despite the European Commission's predictions, the Polish

${ }^{3}$ Corresponding author: d.paraskevadakis@ljmu.ac.uk 
intermodal transport sector still has a range of issues to overcome before it can capture a competitive quantity freight transport. The main barriers that inhibit the development of intermodal transport in Poland are the high external costs (Foltyński, 2014; Gajewska et al., 2015; Bartczak, 2016), the poor quality of the railway infrastructure (Szepietowska, et al., 2012; Rosa, 2013; Gajewska et al., 2015; Bartczak, 2016; Khulova et al., 2016, Biniasz, 2014), the insufficient condition of the container terminals (Szepietowska et al., 2012; Wagner,2014; Gajewska et al., 2015; Bartczak, 2016) and their insufficient number (Szepietowska, et al., 2012; Bartczak, 2016) and also their lack of legal regulations (Engelhardt, 2013; Foltyński, 2014). Perhaps of greatest concern is the condition of the railway infrastructure and the impact that this has upon the allowable speed of rolling stock (Khulova et al., 2016; Bartczak, 2016). This has obvious implications for the timeliness of deliveries (Foltynski, 2014; Khulova et al., 2016) which often lead to potential intermodal customers choosing road transport instead of rail (Biniasz, 2014; Gajewska et al., 2015).

Poland sits at a critical location for a number of important transport corridors. Locally, these link the Baltic to both the Adriatic and the North Sea. However, on a global scale, these corridors also link Asian manufacturers with Western European consumers (European Commission, 2019). Taking this into consideration, Poland is a perfectly sited transit country for international transport. In addition, due to many of these corridors being part of the TEN-T network, the development of the existing intermodal transport options in Poland is ensured through a number of EU funded projects that invest in the improvement of transport infrastructure (Korulczyk, 2015; Foltyński, 2014; Khulova at al., 2016; Wiśnicki et al., 2017). However, it would be a mistake to believe that Polish freight transport infrastructure is inherently underdeveloped. There are a number of strong points, including developed container and ferry seaports, in particular the Baltic Container Terminal (BCT) in Gdynia, the Deepwater Container Terminal (DCT) in Gdansk and the Deutsche Bahn Port Szczecin (DB Port Szczecin) (Burchacz et al., 2012). These have been identified due to their existing strong potential, their current infrastructure, and their investments plans for increasing transshipment efficiency. Simply considering these locations demonstrates that Polish intermodal transport is well prepared for an increase in the container-based carriage of cargo (Burchacz et al., 2012). In addition, the location of a terminal is a crucial indicator of the frequency with which it will be used (Stokłosa et al., 2014). In this case, the relatively short distances between these terminals are an important advantage. Although Poland covers a large area, the distances between its biggest cities are relatively short (less than $200 \mathrm{~km}$ ) so ease of access to terminals makes intermodal freight transport a more attractive option (Wiśnicki et al., 2017). Strategy for Transport Development for 2020 (with perspective for 2030) was a document issued in order to ensure the appropriate development of transport infrastructure in Poland. The document outlined the major barriers in the way of promoting intermodal freight carriage. It also provided some ideas regarding how to support its development. These included such options as lowering the costs for operators (Biniasz, 2014; Foltynski, 2014) and increasing transport reliability (Biniasz, 2014). 


\section{Research Methodology}

This study adopted a methodology that was derived from the research 'Onion' of (Saunders et al., 2016). It was felt by the researchers that, due to the both objective and subjective nature of the research, a pragmatic philosophy were best suited to examining the development of intermodal freight transport in Poland from 2007 to 2016. As the study did not begin with a clear hypothesis, an inductive research approach was pursued. This began with data collection that was then followed by the drawing of conclusions. As (Saunders et al., 2016) emphasised all generalisations, through generic statements, ultimately begin with specific data which is then interpreted. As a result, the research strategy employed initially relied upon a survey of transport professionals from Poland's intermodal transport industry to provide a subjective primary data set. This was then augmented, by archival research of historical secondary data from GUS and UTK that allowed the fact based, objective, evolution of Polish intermodal transport development within the identified timeframe to be established. The study aimed to interpret both data sets together to show the differences and similarities between the opinion of professionals from the intermodal transport industry and the statistical data recording the level of intermodal transport development. A concurrent triangulation approach was utilised as each of these data collection activities were conducted simultaneously. The study focused on a cross-sectional time horizon, that of 2007 to 2016, to enable the evolution of intermodal transport in Poland 'then' to be compared with 'now' (2019). The primary data collected from industry professionals was analysed with the use of SPSS and presented in the form of a Pearson product-moment correlation coefficient that allowed the strength of the relationship between variables and a direction of the relation between them to be measured, whereas, the qualitative and quantitative secondary data that was collected was analysed with the use of Excel and visualised in the form of graphs.

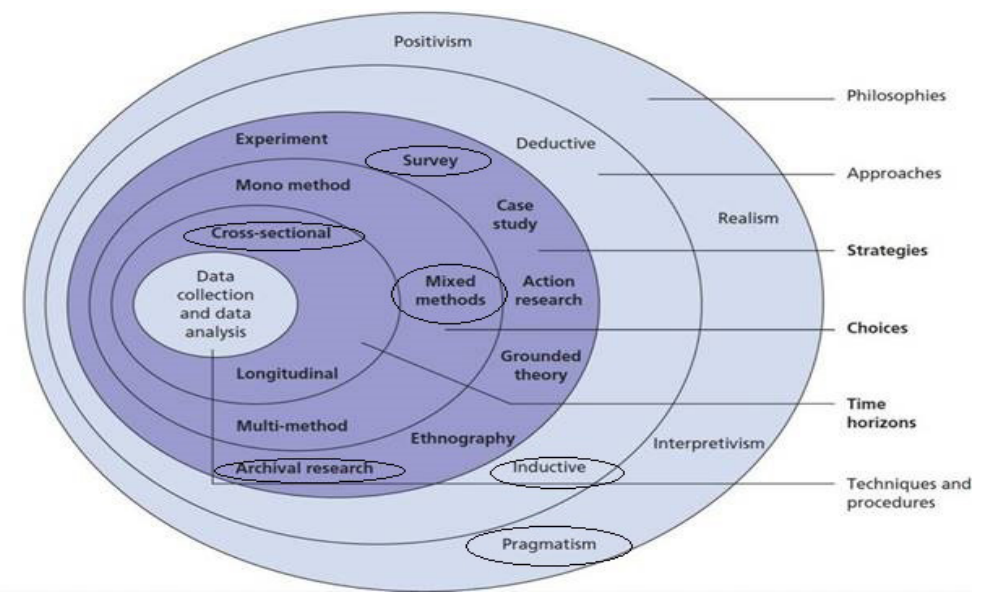

Fig. 1.

The Research 'Onion'

Source: (Saunders et al., 2016; p.108) 


\section{Evolution of Intermodal Transport in Poland 2007-2016}

\subsection{Railway Transport}

Data shows that, despite one drop event in 2009, the share of railway intermodal transport in Poland increased by $5.3 \%$ between 2007 and 2016 (Fig 2.). Over the same period, the use of rail intermodal transport also increased in Germany as well as across the EU as a whole. However, it was a growth of only $0.90 \%$ and $3.6 \%$ respectively. In comparison to Germany and the EU, Poland still represented a significantly low share of railway intermodal transport during this period. The increase of share of railway intermodal transport in this period suggested that intermodal transport solutions are used more willingly.

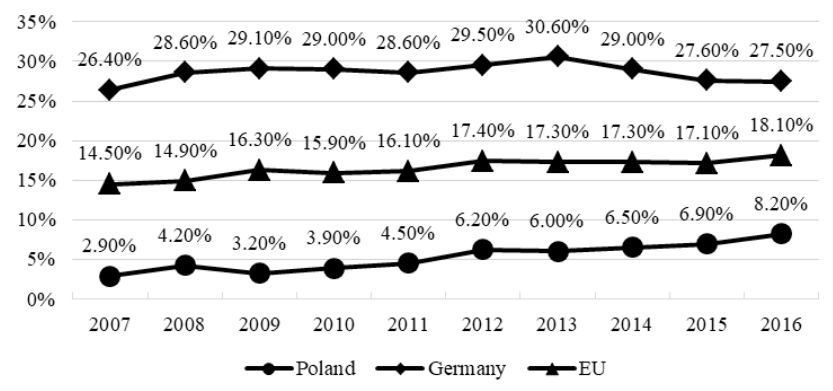

Fig. 2.

A Comparison of the Percent of the Share of Railway Intermodal Transport (Including Containers and Swap Bodies) Based on Tonne-kilometres for Gross Weight of Goods in Poland, Germany and the EU Source: Adapted from (Eurostat, 2018a)

As can be seen from the data (Fig. 3 and 4), a significant increase occurred in container transport in this period. This amounted to an increase of $262.9 \%$ in TKM and $247 \%$ in TEU in comparison to 2007. Again, similar to the share of railway intermodal transport there was one event of decrease in 2009 which came because of the global economic crisis. However, despite this single drop the amount of container transport rose over all between 2007 and 2016.

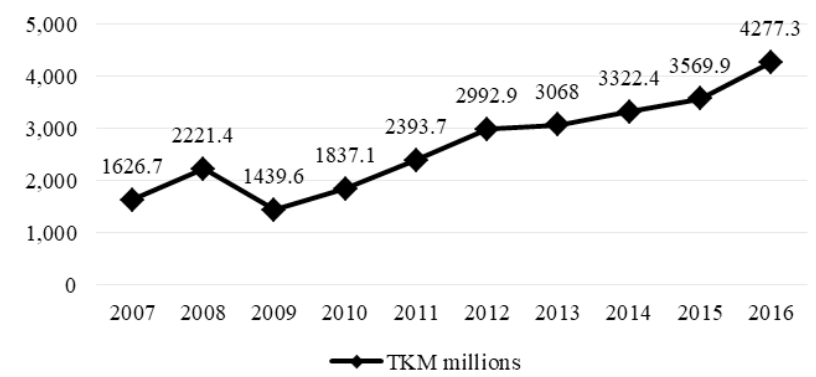

Fig. 3.

Transport of Goods in Containers in Tonne-kilometres Millions by Railway Source: Adapted from: (GUS, 2008; 2009; 2010; 2011; 2012; 2013; 2014; 2015; 2016; 2017) 


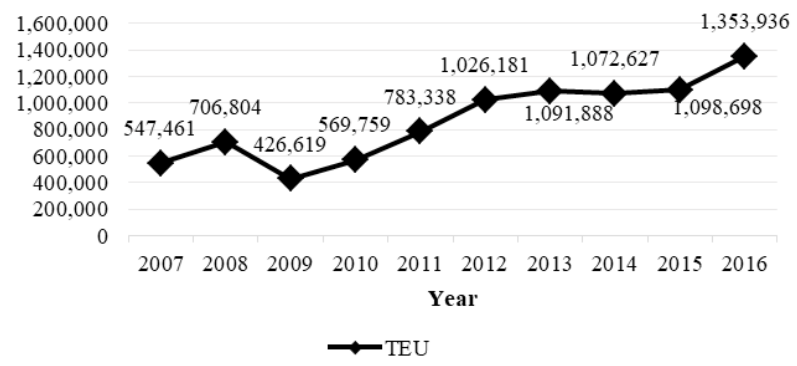

Fig. 4.

Transport of Containers by Standard Gauge Railway Transport Including Large Gauge Measured in TEU Source: Adapted from: (GUS, 2008; 2009; 2010; 2011; 2012; 2013; 2014; 2015; 2016; 2017)

In addition, an increase can also be seen in the number of units of road goods vehicles transported by railway in this period (Fig. 5). Semi-trailers were not transported by standard gauge railway until 2010, but despite this, within 7 years, the number of transported units rose from 30 to 25,816 , representing a growth of $85,953.3 \%$ by 2016 . In comparison to semitrailers, the swap bodies were transported constantly over this period and although there was a sharp drop, lasting from 2013 to 2015 , an upward trend can be seen from 3,990 to 6,532 units transported by railway. This represents an increase of $63.7 \%$. Road vehicles only began being transported by rail in 2008 but between then and 2016 the number of units of road vehicles carried increased, peaking in 2015 with 633 units. This suggests that semitrailers were most often being used to transport goods in this period.

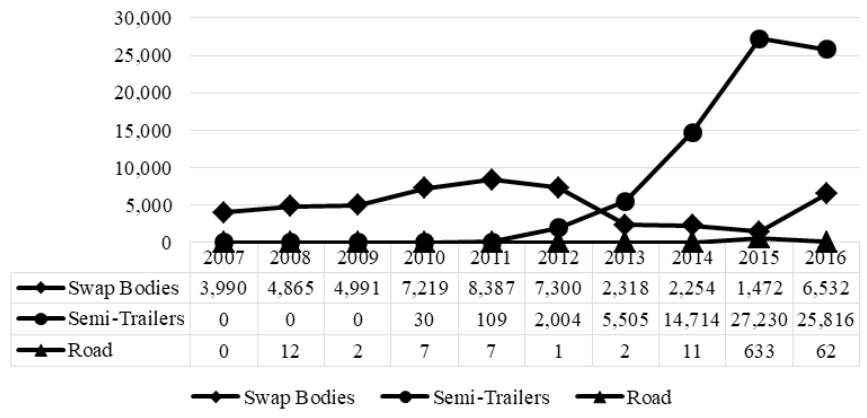

Fig. 5.

Number of Units of Road Goods Vehicles Transported by Standard Gauge Railway Transport, 2007-2016 Source: Adapted from: (GUS, 2008; 2009; 2010; 2011; 2012; 2013; 2014; 2015; 2016; 2017)

Between 2007 and 2016, the use of intermodal railway carriers saw a rise of $100 \%$ from 6 in 2007 to 12 in 2016 (Table 1). No change occurred between 2007 and 2008 and it increased by only one carrier in 2009. In 2010 , a decline resulted in only five carriers remaining on the market. Subsequently, until 2014 , the number of intermodal railway 
carriers increased incrementally each year, as can be seen from the data in Table 1 . The last change occurred in 2014 when the number of intermodal transport carriers increased by 2 to reach a total of 12 . This number then remained the same until 2016.

\section{Table 1}

The Evolution of the Number of the Intermodal Transport Carriers by Railway in Poland, 2007-2016

\begin{tabular}{|c|c|c|c|c|c|c|c|c|c|c|}
\hline Carriers & $\mathbf{2 0 0 7}$ & $\mathbf{2 0 0 8}$ & $\mathbf{2 0 0 9}$ & $\mathbf{2 0 1 0}$ & $\mathbf{2 0 1 1}$ & $\mathbf{2 0 1 2}$ & $\mathbf{2 0 1 3}$ & $\mathbf{2 0 1 4}$ & $\mathbf{2 0 1 5}$ & $\mathbf{2 0 1 6}$ \\
\hline PKP Cargo & $\bullet$ & $\bullet$ & $\bullet$ & $\bullet$ & $\bullet$ & $\bullet$ & $\bullet$ & $\bullet$ & $\bullet$ & $\bullet$ \\
\hline PKP LHS & $\bullet$ & $\bullet$ & $\bullet$ & $\bullet$ & $\bullet$ & $\bullet$ & $\bullet$ & $\bullet$ & $\bullet$ & $\bullet$ \\
\hline DB Schenker & $\bullet$ & $\bullet$ & $\bullet$ & $\bullet$ & $\bullet$ & $\bullet$ & $\bullet$ & $\bullet$ & $\bullet$ & $\bullet$ \\
\hline DB Kolchem & $\bullet$ & $\bullet$ & $\bullet$ & & & & & & & \\
\hline CTL Rail & $\bullet$ & $\bullet$ & & & & & $\bullet$ & $\bullet$ & $\bullet$ & $\bullet$ \\
\hline CTL Logistics & $\bullet$ & & $\bullet$ & & $\bullet$ & $\bullet$ & $\bullet$ & $\bullet$ & $\bullet$ & $\bullet$ \\
\hline CTL Express & & $\bullet$ & $\bullet$ & $\bullet$ & $\bullet$ & $\bullet$ & & & & $\bullet$ \\
\hline Lotos Kolej & & & $\bullet$ & $\bullet$ & $\bullet$ & $\bullet$ & $\bullet$ & $\bullet$ & $\bullet$ & $\bullet$ \\
\hline STK Wroclaw & & & & & $\bullet$ & $\bullet$ & $\bullet$ & & & $\bullet$ \\
\hline Majkoltrans & & & & & & $\bullet$ & & & & $\bullet$ \\
\hline Ecco Rail & & & & & & & $\bullet$ & $\bullet$ & $\bullet$ & $\bullet$ \\
\hline ITL Polska & & & & & & & $\bullet$ & & & $\bullet$ \\
\hline Rail Polska & & & & & & $\bullet$ & $\bullet$ & $\bullet$ & $\bullet$ & $\bullet$ \\
\hline Freightliner & & & & & & & & $\bullet$ & $\bullet$ & $\bullet$ \\
\hline Karpiel & & & & & & & & $\bullet$ & & $\bullet$ \\
\hline Eurotrans & & & & & & & & $\bullet$ & $\bullet$ & $\bullet$ \\
\hline Polzug & & & & & & & & $\bullet$ & $\bullet$ & $\bullet$ \\
\hline Captrain Polska & & & & & & & & & $\bullet$ & $\bullet$ \\
\hline STK & & & & & & & & & & $\bullet$ \\
\hline CD Cargo Poland & & & & & & & & & $\mathbf{1}$ & $\bullet$ \\
\hline The Number of the Carriers & $\mathbf{6}$ & $\mathbf{6}$ & $\mathbf{7}$ & $\mathbf{5}$ & $\mathbf{7}$ & $\mathbf{9}$ & $\mathbf{1 0}$ & $\mathbf{1 2}$ & $\mathbf{1 2}$ & $\mathbf{1 2}$ \\
\hline
\end{tabular}

Source: Adapted from (UTK, 2016b; 2018a; 2018b; 2018c; 2018d; 2018e)

Despite changes in the number of intermodal railway carriers during this time, carriers such as PKP Cargo, DB Schenker and PKP LHS constantly retained a presence in the Polish intermodal transport market but they have some other noteworthy competitors:

- PKP Cargo has the largest share of the Polish railway market in intermodal services. In 2011, their share of this market was $73.28 \%$ (UTK, 2018a). Although this decreased to $48.20 \%$ in 2016, this was still nearly half of the total Polish intermodal railway sector (UTK, 2018e);
- DB Schenker is especially noteworthy contributor to the Polish intermodal railway transport market. Their share of railway intermodal transport increased dramatically from $0.21 \%$ in 2011 to $19.79 \%$ in 2016 (UTK, 2018a; 2018e);

- PKP LHS has been in the market throughout the period of 2007 to 2016 but despite this their share of intermodal transport has remained lower than PKP Cargo. It was $2.20 \%$ in 2011 (UTK, 2018a) and then it declined further to $1.51 \%$ in 2016 (UTK, 2018e);

- Lotos Kolej had been in the intermodal transport market in Poland since 2009 
and it has maintained a relatively strong position. Its share of intermodal transport in railway was $21.42 \%$ in 2011 (UTK, 2018a) but decreased to $15.97 \%$ in 2016 (UTK, 2018e);

- STK was carrier that had the poorest share in railway transport in 2016 because it was only $0.004 \%$ (UTK, $2018 \mathrm{e})$. Data presented in table lindicates that there was a rise of the amount of intermodal the transport carriers between 2007 and 2016 .

The competitiveness of railway intermodal transport remains a concern in the Polish transport sector. The government takes every opportunity to increase the competitiveness of intermodal transport in relation to road. The Ministry of Transport, Construction and Maritime Economy emphasises this in 'The Project of Strategia Rozwoju Transportu do 2020' (Transport Development Strategy until 2020 - SRT Project). One of the many recommendations made through this project is that a reduction of costs for accessing rail infrastructure for intermodal transport is necessary to increase the competitiveness of intermodal transport in the Polish transport sector (MTBGM, 2013).

\subsection{Intermodal Transport with the use of Maritime Transport Mode}

The use of intermodal transport in maritime freight transport grew in the period of 2007 to 2016 in Poland, Germany and in the EU (Fig. 6). Despite a few declines in this period, it had an overall upward trend. Interestingly, the percentage use of intermodal transport solutions in maritime was higher in Poland than in the EU and increased respectively by $6.6 \%$ and $3.8 \%$. However, through all this period Germany presented the highest use of intermodal transport in maritime freight transport.

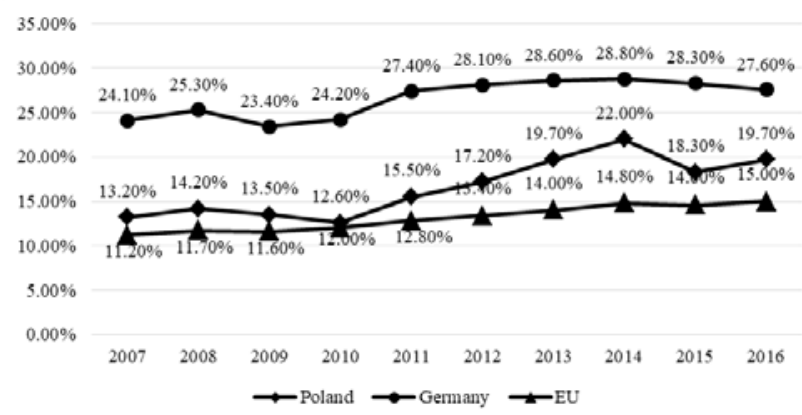

Fig. 6.

A Comparison of the Percent of the Unitisation in Maritime Freight Transport - Tonnes for Gross Weight of Goods in Poland, Germany and the EU - Short Sea Shipping

Source: Adapted from: (Eurostat, 2018b)

It can also be seen from the available data (Fig. 7) that the number of container units transported from and to main ports in Poland rose throughout this period (an increase of $202 \%)$, despite its decrease in neighbouring
Germany (a decrease of $0.8 \%$ ). However, regardless of this difference in the overall trend, Poland's volume of container transport in units remains significantly lower than Germany's. 


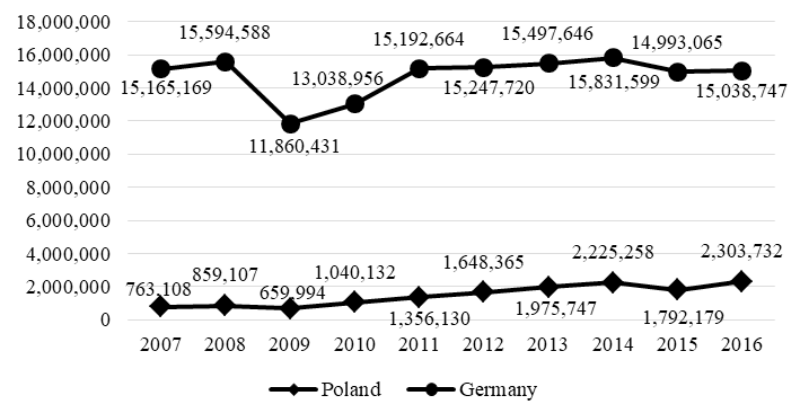

Fig. 7.

Comparison of the Evolution of Volume of Container Transport in Units from/to Main Ports in Poland and Germany

Source: Adapted from: (Eurostat, 2019a; 2019b; 2019c; 2019d; 2019e)

\subsection{Intermodal Transport with the use of Road Transport}

The unitisation in intermodal road freight transport had an upward trend during this period in Poland, Germany and the rest of the EU. However, data for the EU was only available for the period 2010 to 2014 (Fig.
8). Despite many small-scale fluctuations that occurred, intermodal road transport increased slightly by $0.2 \%$ in Poland between 2007 and 2016. By comparison, it rose by $8.40 \%$ in Germany. In Poland, it appears that road transport using intermodal transport solutions are still at an early stage in comparison to Germany and the wider EU.

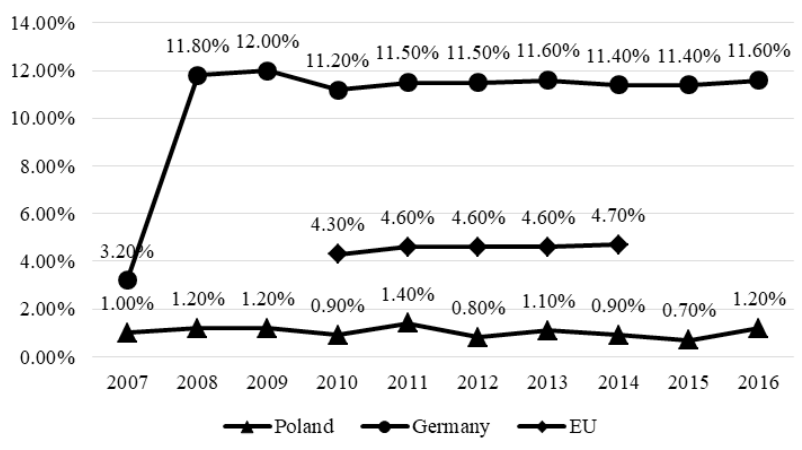

Fig. 8.

A Comparison of the Percent of the Unitisation in Intermodal Road Freight Transport - Tonne-Kilometres for Gross Weight of Goods in Poland, Germany and the EU - Large Containers, 2007-2016 Source: Adapted from: (Eurostat, 2018c) 
It can be noticed that overall container transport by road also had an upward trend, with a change of $29 \%$ (Fig. 9). Ultimately, the marked declines that occurred in this period did not manage to reduce the overall increase in the utilisation of intermodal transport. Indeed, the data indicates that the lengths of the routes, which transported goods, grew in this period.

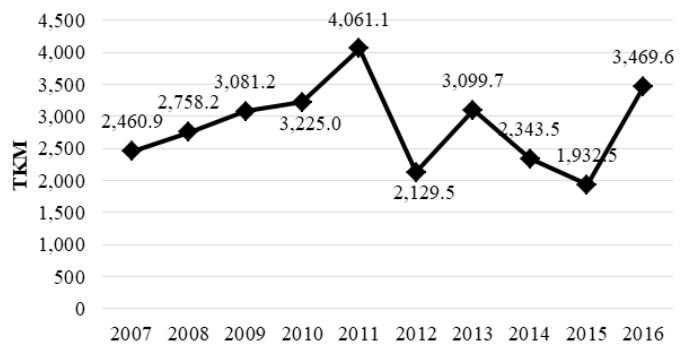

Fig. 9.

Transport of Goods in Container by Road Transport (Tonne Kilometres in Millions)

Source: Adapted from: (GUS, 2008; 2009; 2010; 2011; 2012; 2013; 2014; 2015; 2016; 2017)

\section{Intermodal Infrastructure}

Railway infrastructure is a factor that inhibits the development of intermodal transport in Poland. Many operators perceive it as the weak link that deters them from making use of a multimodal approach to their shipping activities. UTK (2012) and Stawiński (2016) emphasise that the rail infrastructure is poor and in desperate need of modernisations. Specifically, the condition of the railways is such that goods transported over the same distance take noticeable longer by rail than by road (Fig. 10). Furthermore, the average railway commercial speed is low when compared to that of other nations. It was approximately 35 $\mathrm{km} / \mathrm{h}$ in Poland in 2011. This results in poor punctuality, and additionally, in many cases, ensures that the delivery time of a shipment is longer than by road (UTK, 2012, 2013). Although the average for domestic intermodal transport was $28 \mathrm{~km} / \mathrm{h}$ in 2014 (higher by $5 \mathrm{~km} / \mathrm{h}$ than the average commercial speed of freight trains), it is still a poor performance (UTK, 2016a). Based on this it can clearly be seen that there is a vast mismatch between the level of development of the road network and the rail network in Poland.

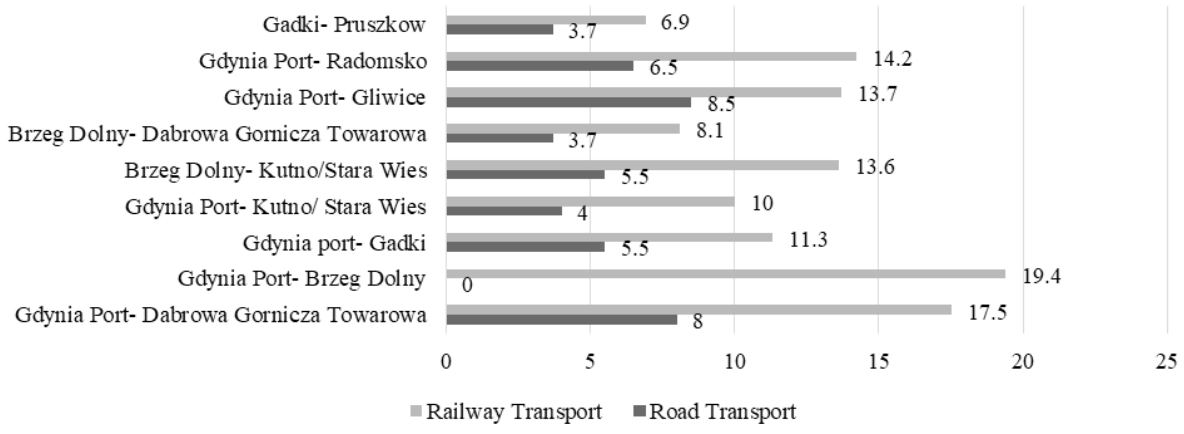

Fig. 10.

Comparison of Time Route - Road Transport vs. Railway Transport

Source: Adapted from (Stawiński, 2016) 
The results of UTK $(2012,2013)$ and Stawiński (2016) are similar in that they find that the access costs to railway infrastructure are particularly high. According to UTK (2012), the costs for access to the rail infrastructure were the lowest between 2007 and 2009. During this time, because of discounts offered for intermodal transport, rail costs were lowest for intermodal trains rather than 'standard' freight trains. As UTK (2012) emphasises, in the schedule 2010/2011, a discount for rail freight transport no longer applied to intermodal transport as it was then only intended for loaded wagons. Although this changed in the schedule 2011/2012 and intermodal transport received a $25 \%$ discount for access to the rail infrastructure, the cost for intermodal carriers remained significantly high in comparison to the pre 2010 years schedule (UTK, 2012). Regardless, despite the discount for intermodal transport, the costs for access to infrastructure on most routes were lower for road transport than rail transport (Fig. 11). Data from figure 11 indicates that, despite the discount for the intermodal trains, it did not have an impact on the lower costs for the access to the rail infrastructure borne by carriers.

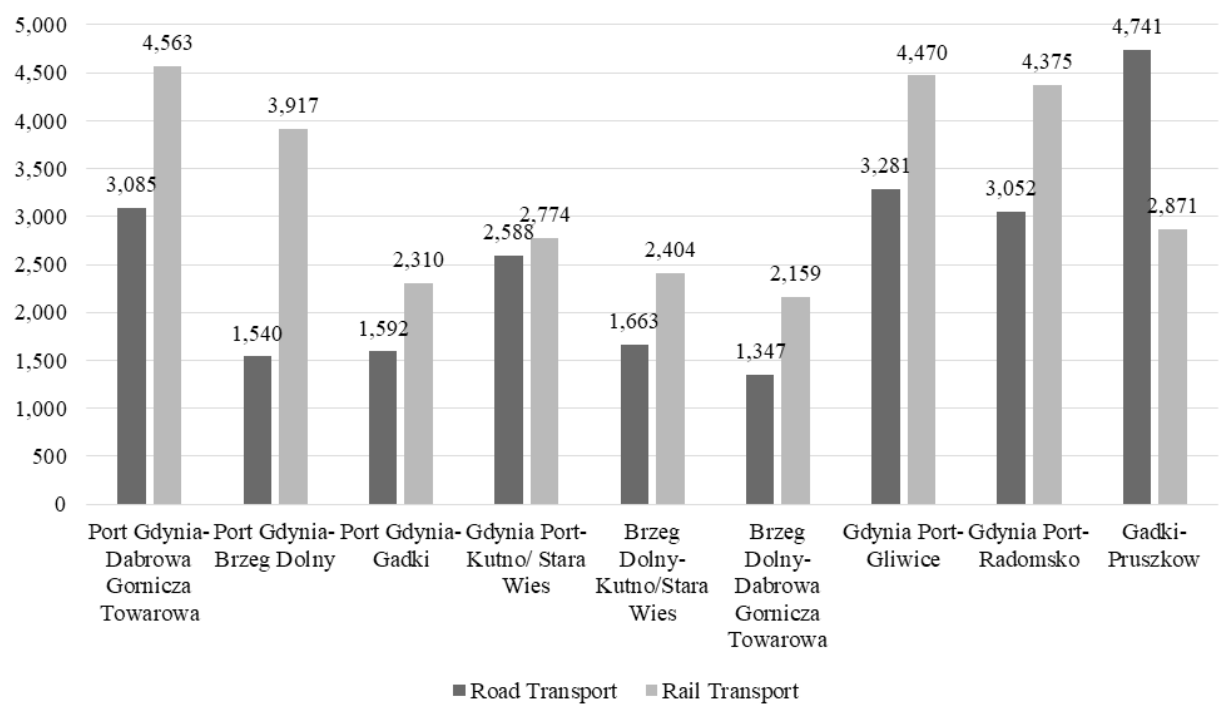

Fig. 11.

Comparison of the Costs of Access to Infrastructure - Road vs. Rail Transport, 2015/2016 Source: Adapted from (Stawinski, 2016)

According to GUS (2017), in 2016, Poland was in possession of thirty-five active intermodal terminals (Fig. 12). Of these, seven were sea terminals, connecting sea with rail transport and sea with road transport and the remaining twenty-eight were terminals connecting rail with road.
These were deployed non-uniformly in Polish territory with a noticeable lack of terminals in the north-eastern part of the country. Typically, there was a distance of $250 \mathrm{~km}$ to $570 \mathrm{~km}$ between the road transport terminals and $240 \mathrm{~km}$ to $550 \mathrm{~km}$ for rail transport (Stawiński, 2016) (Fig.13). 


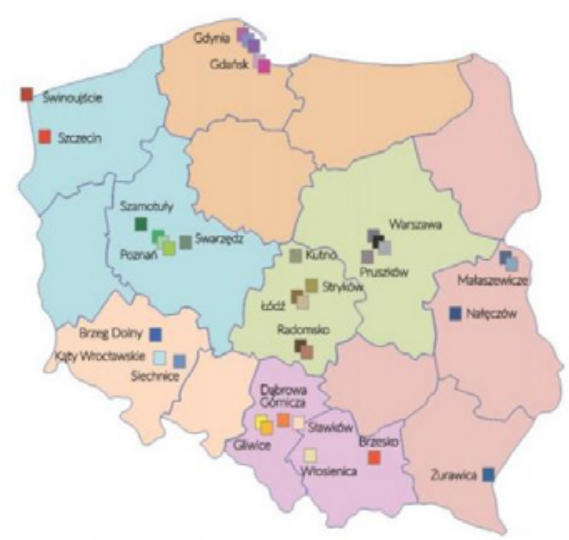

Fig. 12.

Deployment of Intermodal Terminals in Poland in 2016

Source: (GUS, 2017)

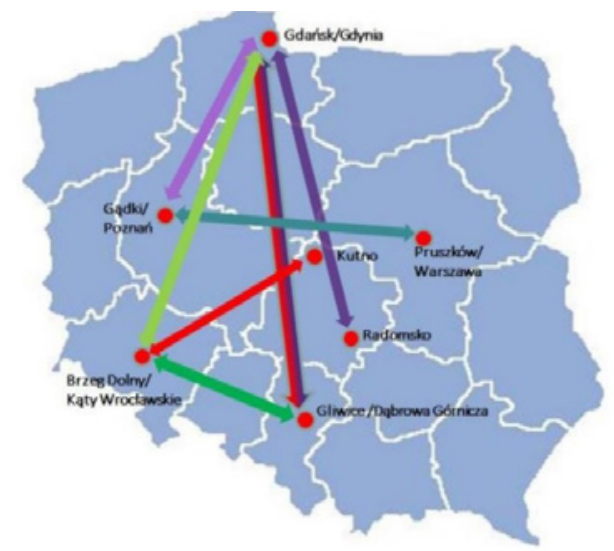

Fig. 13.

Deployment of Container Terminals that were used in Intermodal Transport in Poland in 2015

Source: (Stawiński, 2016; p.8)

\section{Policy and EU Projects}

As already stated, railway infrastructure is an essential factor inhibiting intermodal transport development in Poland. To address this, the Ministry of Transport, Construction and Maritime Economy (2013) aimed to support its development until 2020 (with a perspective up to 2030) focusing in particular on the modernisation of the infrastructure, such as building new intermodal terminals and regional logistics centres as well as the expansion and extension of existing terminals. The strategy pursued included incorporating inland waterway transport into the intermodal transport chain by adapting intermodal transport parameters to support transport between intermodal 
seaports in Poland (MTBGM, 2013). With Poland's participation in the TEN-T corridor programme, and its member status of the EU, modernisation of its infrastructure is ensured. Completed projects of note include 'Safer, quicker journeys on Poland's A1 motorway' (European Commission, 2011), road and rail network extensions in the Gdansk port (European Commission, 2016a; 2016b) and an accompanying improvement to the port's fairway that was started in 2016 (European Commission, 2016c).

It is also recognised that, an efficient information flow between the customers and the intermodal transport providers is essential. This could be improved by application of new technology and, as (MTBGM, 2013) indicates, the best European solutions will be used in Poland (MTBGM, 2013). Again, EU funded projects will support Polish innovation and development in transport and in this case through e-Freight Implementation Action (e-Impact). E-Impact is a part of the CEF

\section{Table 2}

Reliability Statistics of the Survey Results

\begin{tabular}{|l|l|}
\hline Reliability Statistics \\
\hline Cronbach`s Alpha & N of Items \\
\hline .841 & 50 \\
\hline
\end{tabular}

\subsection{Quality of the Intermodal Transport Services}

Using the Servqual survey to collect data from professionals with connections to the intermodal transport sector enabled answers to be generated to a range of questions aimed at determining what level of intermodal transport service exists in Poland. The results of the survey were analysed using SPPS and suggested that mean scores of
Project in the core network corridors of the Atlantic, Mediterranean and Baltic-Adriatic (European Commission, 2015). The major aim of the project being a reduction of costs and time taken for exchanging information between parties involved in goods transport (European Commission, 2015). The Polish ports that have taken part in the project are Gdansk, Gdynia, Szczecin and Swinoujscie (European Commission, 2015).

\section{Research}

A survey was conducted of thirty individuals who were professionals with connections to intermodal transport in Poland. The majority of the respondents who took part in the survey were service providers (86.7\%) and $10 \%$ of them were customers, only one person was related to education. The method which was used to examine the consistency of the research was Cronbach `s Alpha which was found to be 0.844 (Table 2). This value indicates a high level of internal consistency for the data collected.

expectations in relation to services are higher than their assessment and were respectively 86.77 and 74.07 .

The correlation was examined between expectations and assessments of the quality of the intermodal transport services in Poland to determine whether a relationship existed between them. The results suggest a significant correlation at level 0.05 between the expectations and the 
assessment (Fig.14). The strength of the relation between variables was 0.391 and its value was 0.033 . The relationship between the expectations and the assessments shown in Fig. 14 indicates that there is a linear relationship between the variables with a few outliers. R squared gave 0.153 therefore $15.3 \%$ of the variance for the expectations is associated with the variance of the assessments.

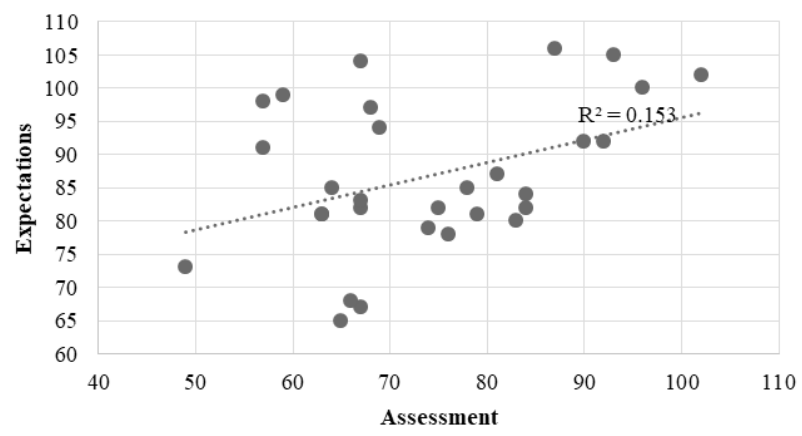

Fig. 14.

Scatter of the Pearson Correlation between Expectations and Assessment of the Quality of Intermodal Transport Services in Poland

The study also focused on subsections indicated that the expectations of intermodal of the services as: tangibles, reliability, transport were not matched by the existing responsiveness, assurance and empathy. These intermodal transport services (Fig. 15).

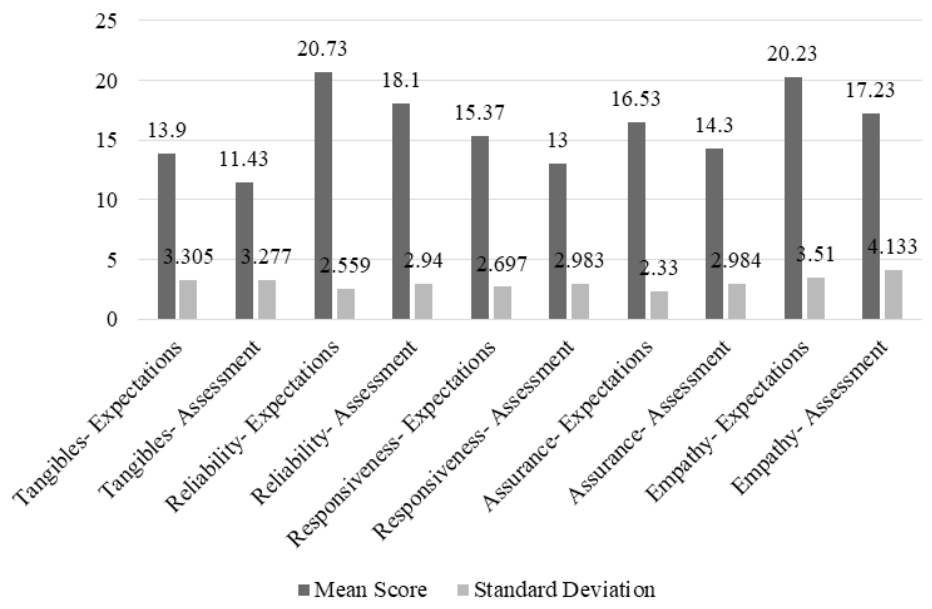

Fig. 15.

Mean Scores and Standard Deviations for the Expectation and Assessments of the Intermodal Transport Services in Poland 
It can be seen from data in Fig.15, that the greatest mean difference score between the expectations and the assessment is in the empathy section (3) and the least difference is between the expectations and the assessment of the assurance (2.23). Moreover, the assurance expectations show the smallest standard deviation that is 2.330 whereas the empathy assessment shows the greatest standard deviation that is 4.133 . Data from Fig. 15 indicates that there is a difference between expectations and assessments of the quality of the intermodal transport services.
The correlation of this data was computed to assess the strength of the relationship between the tangibles expectations and the tangibles assessment.

The results indicated a significant positive correlation between the variables (Fig.16), which was 0.561 and its significance was 0.001 . As Fig. 16 indicates there was an upward trend of the association and $\mathrm{R}$ squared implied that $31.5 \%$ of the variance for the tangibles expectations is associated to the variance of the tangibles assessment.

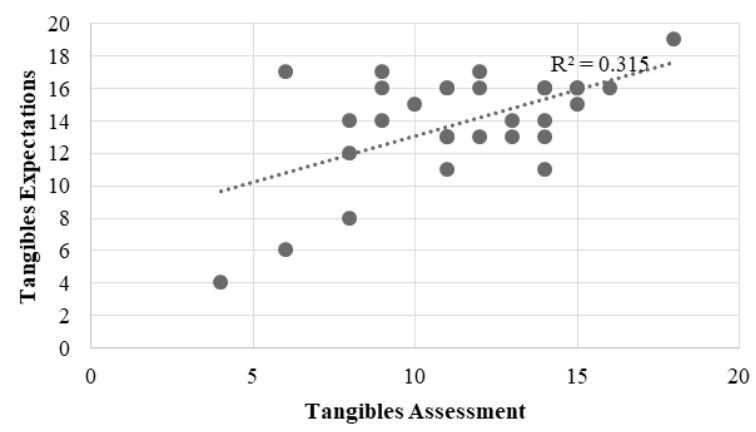

Fig. 16.

Scatter of the Pearson Correlation between the Tangibles Expectations and the Tangibles Assessment of the Quality of Intermodal Transport Services in Poland

Further to this, a positive significant correlation of 0.01 level was found between assurance expectations and assessment and it was 0.546 (Fig.17). The determination of the correlation coefficient was 0.002 . From data in Fig.17, it can be seen, that there was an upward and linear correlation with a few outliers between the variables. 0.299 is the result of squaring the strength of the correlation and implies that $29.9 \%$ of the variables are associated between each other. 


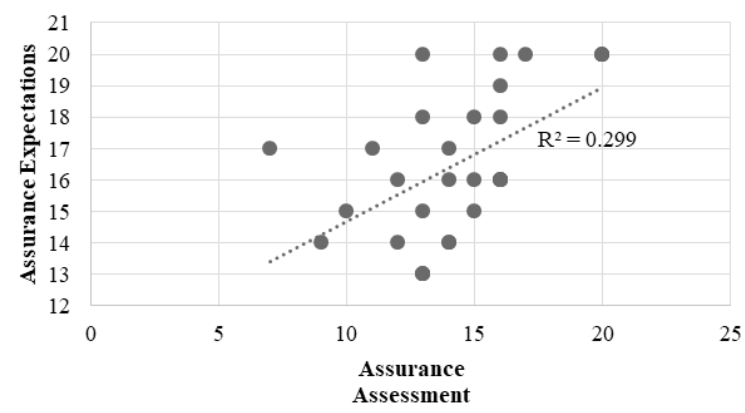

Fig. 17.

Scatter of the Pearson Correlation between the Assurance Expectations and the Assurance Assessment of the Quality of Intermodal Transport Services in Poland

Additionally, the correlation between the empathy expectations and assessment were examined and it was found that a positive significant relationship exists between the variables. It can be seen from data that the variables are positively associated with a linearly upward trend (Fig.18). The bivariate Pearson correlation was 0.555 and its determination was 0.001 . Moreover, $\mathrm{R}$ squared suggested that $30.8 \%$ of the variance for the empathy expectations is associated with the variance of the empathy assessment.

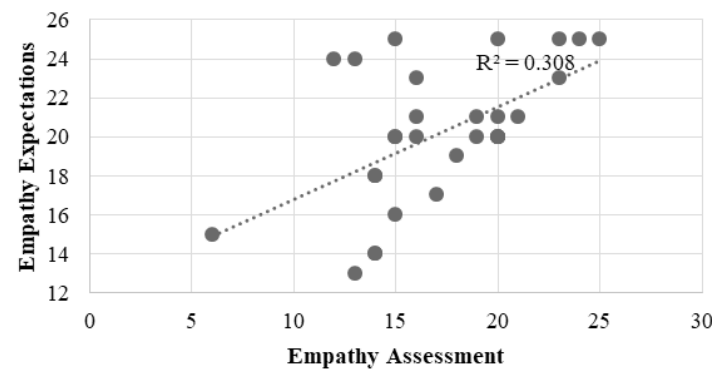

Fig. 18.

Scatter of the Pearson Correlation between the Empathy Expectations and the Empathy Assessment of the Quality of Intermodal Transport Services in Poland

Finally, the correlation to assess the strength of the relationship between the responsiveness expectations and the responsiveness assessment was computed (Fig. 19). The results indicated that there was a positive significant correlation between the variables. There is a correlation with an uphill slope with a few outliers between the variances. The strength of the correlation was 0.514 and its determination was 0.004 . Squaring $\mathrm{R}$ indicated that $26.5 \%$ of the responsiveness expectations were overlapped by the responsiveness assessment. 


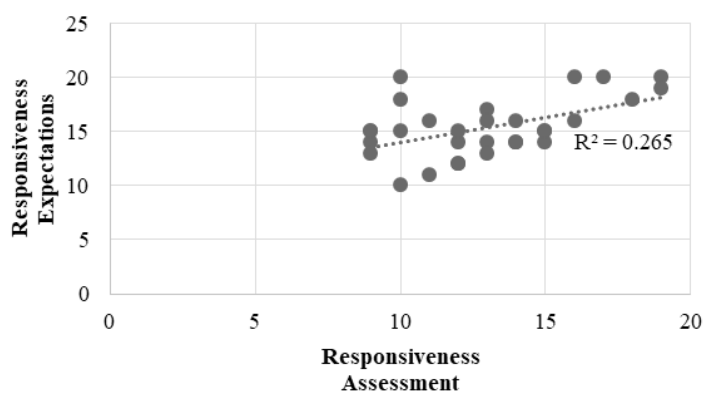

Fig. 19.

Scatter of the Pearson Correlation between the Responsiveness Expectations and the Responsiveness Assessment of the Quality of Intermodal Transport Services in Poland

\subsection{The Condition of Intermodal Transport in Poland According to the Respondents}

The second part of the survey considered the opinions of professionals from within Poland's freight transport sector. It was specifically geared towards studying the level of intermodal transport development in Poland. The results presenting mean score and standard deviation are shown in Fig. 20. The examined statements are as follows:

1. Rail infrastructure is poorly developed in Poland;

2. The reliability of rail freight services is high;

3. The costs for access to rail infrastructure are excessive;

4. The reputation of rail services is poor in Poland;

5. Intermodal transport is time efficient. As much as road transport in Poland;

6. The quality of the access infrastructure to the intermodal terminals is sufficient and adequate in Poland;
7. The number of the container terminals is appropriate to demand in Poland;

8. The container terminals have not enough space in their storage yards in Poland;

9. The container terminals are in possession of insufficiently developed equipment; thus, they are not able to provide the efficient intermodal services;

10. The participation of Poland in the transport corridors and EU projects ensures the development of intermodal transport;

11. Polish transport regulations are insufficient to support the development of intermodal transport;

12. The Polish government provides insufficient support for the development of intermodal transport;

13. The use of intermodal transport grows constantly with every year in Poland;

14. Intermodal transport is competitive in comparison to road transport in Poland. 


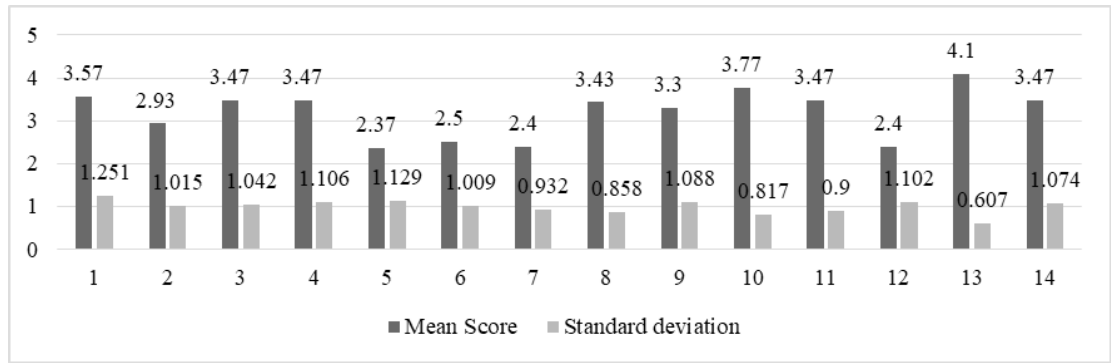

Fig. 20.

The Mean Scores and Standard Deviations for the Examined Statements in the Third Part of the Survey

\section{Analysis and Discussion}

According to the findings, the use of intermodal transport has increased every year in Poland during the period being considered by this work. The results showed a significant rise in the share of intermodal transport making use of rail between 2007 and 2016 (Fig.2). Although this is positive, it still represented a lower share of intermodal transport for rail than in Germany or the EU average.

Maritime transport is also an important part of intermodal transport in Poland. The results show an upward trend to the share of intermodal transport in the maritime mode (Fig.6). Perhaps surprisingly, Poland represented a higher share of intermodal transport in maritime transport than the EU average. The research findings demonstrated that despite several drops, a significant increase of the use of intermodal transport in maritime took place over this period. Furthermore, regarding the maritime transportation of containers, the research findings displayed a significant increase across this period (Fig.7). However, despite this, when compared to Germany, Poland presented a much lower number of container units being transported to and from its main ports. This shows that significant progress was made by Poland in the volume of maritime container units being transported over this period.

The research results present a slight rise in the use of road transport in the researched period in Poland and across the EU (Fig. 8). However, Poland represented a lower share of intermodal road freight transport than Germany and the EU average (20102014). However, the most interesting finding indicated a significant growth of the road goods vehicles transport by railway (Fig. 5). Despite semitrailers having the largest share carried among these road vehicles, there was also an accompanying significant increase in the total amount of road goods vehicles transported by rail. A possible explanation for this might be the growing tendency to look for the solutions aimed at using intermodal transport in Poland and the increasing awareness of the benefits of this transport solution. In addition, the number of intermodal railway carriers rose over this period and this ensured the competitiveness on the intermodal transport sector. Despite PKP cargo's share of intermodal transport market decreasing over this period, it still 
has a strong position carrying almost half of the mode's share. During this period, new carriers entered the Polish market, indicating that intermodal transport developed and has the potential for further development.

The study indicated that the railway infrastructure in Poland still needs some improvements in order to meet demand of intermodal transport. Furthermore, the research found that the time taken by road transport is significantly more efficient than railway transport over similar length journeys. As a result, road transport is more time competitive. In addition, the railway carriage of freight is perceived poorly by its potential customers who do not trust the punctuality and reliability of railway freight services. A possible explanation for these results is that punctuality is not helped by the low commercial speeds of rolling stock and the quality of available infrastructure does not meet the expectations of those involved in the industry.

The other barrier that seems to inhibit the development of intermodal transport in Poland is the container terminals. The study's findings show that the distribution of intermodal terminals is inappropriate (Fig. 12 and Fig. 13) as there is a complete lack of a terminal in the north-eastern part of Poland. This finding agrees with the survey results as the majority of the respondents also considered the number of container terminals in Poland as being inadequate to meet demand. Additionally, the research identified that survey participants perceived there to be a lack of sufficient equipment in the terminals, accompanied by an insufficient amount of space in storage yards, and that this affects the efficiency of intermodal transport in Poland. This indicates that the Polish transport sectors requires investments to be made in terminal equipment and an increase in the number of terminals to ensure an increase in the uptake of intermodal transport options for the carriage of freight. Further to the points above the survey participants believe that, the access infrastructure to terminals is insufficient to meet demand and is therefore an inhibitor to the development of intermodal transport in Poland.

Worryingly, research findings suggest that, regardless of the available intermodal discount, road transport is perceived as being much more competitive than railway transport. In addition, survey respondents considered the cost for access to the rail infrastructure as excessive. Despite this, perhaps surprisingly, according to the survey respondents, intermodal transport is a competitive option when compared to road transport. This could possibly be explained by the role of the Polish government and their legal regulations. The relevant legal regulations do not focus on an appropriate discount, or other solution, to decrease the fees for access to the railway infrastructure to make rail transport more competitive. However, as survey participants stated the Polish government is clearly missing an excellent opportunity as industry members are behind the idea of intermodal transport.

The research findings demonstrate that EU policy plays a major supporting role in promoting the development of intermodal transport in Poland. Many EU funded projects were completed in this period. Perhaps the most relevant is related to infrastructure modernisation of part of Poland's motorway network. In addition, two other projects were started which focused on the improvement of the Gdansk port in order to moderate the road, railway infrastructure 
and improve the fairway to improve the port's competitiveness. Moreover, the EU supported Poland in the application of innovation through the e-Impact project that enabled a quick exchange of information between the parties involved in the transport of freight. A major part of the EU funds supported infrastructure modernisation and innovation in Poland due to its significant position on identified transport corridors. As a result, these investments are expected to be beneficial on an international scale.

A change of the policy behind transport regulations would be a crucial step towards increasing the competitiveness of intermodal transport in Poland. The respondents to the survey recognise that intermodal transport is competitive when compared to road transport. Although discounts granted for intermodal railway carriers do appear to have an impact on the increase of intermodal transport it still seems to be insufficient, as road transport costs remain lower than intermodal transport in Poland. A possible next step would be for the state to look at why they are covering the external costs for road carriers whilst not doing the same for rail carriers. Pursuing this approach, whilst time attempting to promote intermodal freight transportation is counter-productive. If the Polish government put forward policies that led to road freight hauliers paying their own external costs then this would deliver a more even playing field and go a long way to promoting an increased use of intermodal transport in Poland.

\section{Conclusions}

The main conclusions of this study, regarding the evolution of intermodal transport in Poland and its comparison to the other EU members, are as follows. Despite fluctuations within the transport sector, the use of intermodal transport in Poland has increased in the last decade. In addition, despite one decline, intermodal transport in railway transport has increased significantly over the period of 2007-2016. However, the share of intermodal transport that makes use of rail is still lower than Germany's and the EU average. Nevertheless, over the identified period, maritime transport had the biggest share of intermodal transport among other transport modes. A significantly greater share of intermodal transport was performed by the maritime mode in Poland than compared to the EU average, but this was still lower than in comparison to Germany. By comparison, the share of intermodal transport in road transport was insignificant and dropped over this period. Although the transport sector is dominated by the road mode, the study showed an increase in the use of rail to transport road vehicles. This suggests an increased interest in looking for alternative transport solutions and the use of intermodal transport as an option. Taking all of this into account, it can be seen that whilst Poland still needs to apply some changes to equalize the level of transport use in comparison to other EU countries there is potential in railway and maritime transport to deliver this.

The main factor that inhibits the development of intermodal transport is the poor quality of the rail infrastructure influencing the punctuality and reliability of rail services. This leads to the time efficiency of intermodal transport being significantly lower than that of road transport alone and affects the reputation of the rail mode in Poland and the willingness to use its services. In addition, the location and the number of the container terminals, as well as their equipment, are inappropriate. 
The research found that EU policy has actively contributed to the development of intermodal transport within Poland. Modernisation and other investment in transport infrastructure were made with significant EU support through a variety of projects. These delivered much sought after improvements that led to an increase in the competitiveness of intermodal transport that can be seen in the increased uptake of intermodal transport solutions. Despite this, the research also found that high cost remains a challenge for intermodal transport and access infrastructure to terminals remains a problem despite a number of completed EU funded infrastructure projects. This is to such an extent that, despite discounts to the cost of accessing the rail infrastructure, intermodal transport is still not as popular as road transport. Polish transport policy appears to favour road transport. If legal regulations persist in covering an element of the external costs generated by road transport, whilst at the same time forgetting about intermodal transport, it will be difficult for Poland to achieve the maximum competitiveness for its intermodal transport options.

\section{References}

Bartczak, K. 2016. Analysis of barriers to the development of intermodal transport in Poland [In Polish: Analiza barier rozwoju transport intermodalnego], Organizacja i Zarzadzanie 17(4): 120-126.

Biniasz, D. 2014. [In Polish: Transport intermodalny w Polsce- wybrane aspekty rozwoju], Logistyka 2014(6): 1982-1987.

European Commission. 2011. Safer, quicker journeys on Poland's A1 motorway. Available from Internet: <https://ec.europa.eu/inea/sites/inea/files/download/ project_fiches/poland/fichenew_2005p192602s_final. pdf $>$.
European Commission. 2015. e-Freight Implementation Action (e-Impact). Available from Internet: <https:// ec.europa.eu/inea/sites/inea/files/fiche_2014-eu-tm0686-s_final.pdf $>$.

European Commission. 2016a. Design and environment documentation for the expansion and modernisation of core network node in the Port of Gdansk concerning road and rail infrastructure. Available from Internet: $<$ https://ec.europa.eu/inea/sites/inea/files/fiche_2015pl-tm-0280-s_final.pdf $>$.

European Commission. 2016b. Extension and modernisation of road and railway network in the Gdansk outer port. Available from Internet: <https:// ec.europa.eu/inea/sites/inea/files/fiche_2015-pl-tm0372-m_final.pdf $>$.

European Commission. 2016c. Modernisation of the fairway, expansion of the quay and improvement of navigation in the internal Port in Gdansk. Available from Internet: <https://ec.europa.eu/inea/sites/inea/ files/fiche_2015-pl-tm-0413-w_final.pdf $>$.

European Commission. 2019. Rail. The corridors. Available from Internet: <https://ec.europa.eu/ transport/modes/rail/ertms/corridors_en $>$.

Eurostat. 2018a. Unitisation in rail freight transporttonne-kilometre for gross-gross weight of goods. Available from Internet: <http://appsso.eurostat. ec.europa.eu/nui/show.do?dataset =tran_im urail\&lang $=\mathrm{en}>$.

Eurostat. 2018b. Unitisation in maritime freight transport - tonnes for gross weight of goods. Available from Internet: <https://appsso.eurostat.ec.europa. eu/nui/show.do?dataset=tran_im_umar\&lang=en $>$.

Eurostat. 2018c. Unitisation in road freight transport - tonne-kilometre for gross weight of goods. Available from Internet: <https://appsso.eurostat.ec.europa. eu/nui/show.do?dataset=tran_im_uroad\&lang=en $>$. 
Eurostat. 2019a. Volume of containers transported to/ from main ports - quarterly data (2007 - 2008). Available from Internet: <https://appsso.eurostat.ec.europa.eu/ nui/show.do?dataset=mar_go_qm_c2008\&lang $=e n>$.

Eurostat. 2019b. Volume of containers transported to/from main ports - quarterly data (2009 - 2010). Available from Internet: <https://appsso.eurostat. ec.europa.eu/nui/show.do?dataset $=$ mar_go_qm_ c2010\&lang=enc2010>.

Eurostat. 2019c. Volume of containers transported to/from main ports - quarterly data (2011 - 2012). Available from Internet: <https://appsso.eurostat. ec.europa.eu/nui/show.do?dataset $=$ mar_go_qm_ c2012\&lang $=$ en $>$.

Eurostat. 2019d. Volume of containers transported to/from main ports - quarterly data (2013 - 2014). Available from Internet: <https://appsso.eurostat. ec.europa.eu/nui/show.do?dataset $=$ mar_go_qm_ c2014\&lang=en $>$.

Eurostat. 2019e. Volume of containers transported to/ from main ports - quarterly data (2015 - 2016). Available from Internet: <https://appsso.eurostat.ec.europa.eu/ nui/show.do?dataset=mar_go_qm_c2016\&lang=en $>$.

Foltyński, M. 2014. Barriers limiting the development of intermodal transport in Poland- the perspective of business and public administration, LogForum 10(2):141151.

Gajewska, T.; Szkoda, M. 2015. Evaluation of the competitiveness of intermodal transport [In Polish: Ocena konkurencyjności transportu intermodalnego], Logistyka 2015(3): 1355-1363.

GUS. 2008. Główny Urząd Statystyczny. Transport performance in 2007 [In Polish: Transport wyniki działalności w 2007]. Available from Internet: <https:// stat.gov.pl/cps/rde/xbcr/gus/transport_wyniki_ dzialalnosci_2007.pdf $>$.
GUS. 2009. Główny Urząd Statystyczny. Transport performance in 2008 [In Polish: Transport wyniki działalności w 2008]. Available from Internet: <https:// stat.gov.pl/cps/rde/xbcr/gus/til_transport_wyniki dzialalnosci_2008.pdf $>$.

GUS. 2010. Główny Urząd Statystyczny. Transport performance in 2009 [In Polish: Transport wyniki działalności w 2009]. Available from Internet: <https:// stat.gov.pl/cps/rde/xbcr/gus/til_transport_wyniki dzialalnosci_2009.pdf $>$. [Accessed: $24^{\text {th }}$ June 2018].

GUS. 2011. Główny Urząd Statystyczny. Transport performance in 2010 [In Polish: Transport wyniki działalności w 2010]. Available from Internet: <https://stat. gov.pl/obszary-tematyczne/transport-i-lacznosc/transport/ transport-wyniki-dzialalnosci-w-2010-r-,9,10.html>.

GUS. 2012. Główny Urząd Statystyczny. Transport performance in 2011 [In Polish: Transport wyniki działalności w 2011]. Available from Internet: <https:// stat.gov.pl/cps/rde/xbcr/gus/tl_transport_wyniki_ dzialalnosci_2011.pdf $>$.

GUS. 2013. Główny Urząd Statystyczny. Transport performance in 2012 [In Polish: Transport wyniki działalności w 2012]. Available from Internet: <https:// stat.gov.pl/cps/rde/xbcr/gus/tl_transport_wyniki_ dzialalnosci_2012.pdf $>$.

GUS. 2014. Główny Urząd Statystyczny. Transport performance in 2013 [In Polish: Transport wyniki działalności w 2013]. Available from Internet: <https://stat.gov.pl/files/gfx/portalinformacyjny/ pl/defaultaktualnosci/5511/9/13/1/transport_wyniki_ dzialalnosci_2013.pdf $>$.

GUS. 2015. Główny Urząd Statystyczny. Transport performance in 2014 [In Polish: Transport wyniki działalności w 2014]. Available from Internet: <https://stat.gov.pl/files/gfx/portalinformacyjny/ pl/defaultaktualnosci/5511/9/14/1/transport_wyniki_ dzialalnosci_2014.pdf >. 
GUS. 2016. Główny Urząd Statystyczny. Transport performance in 2015 [In Polish: Transport wyniki działalności w 2015]. Available from Internet: <https://stat.gov.pl/files/gfx/portalinformacyjny/ $\mathrm{pl} /$ defaultaktualnosci/5511/9/15/1/transport_wyniki_ dzialalnosci_2015.pdf $>$.

GUS. 2017. Główny Urząd Statystyczny. Transport performance in 2016 [In Polish: Transport intermodalny w Polsce w 2016]. Available from Internet: <https:// stat.gov.pl/obszary-tematyczne/transport-i-lacznosc/ transport/transport-intermodalny-w-polsce-w2016-r-,14,1.html>.

Khulova, L.; Sprochova, L. 2016. Importance of TEN-T corridors in the development of infrastructure. Example of Visegrad Group Countries, Studia Commercialia Bratislavensia 9(33): 49-57.

Korulczyk, J. 2015. Prospects of the development of the intermodal transport in Poland [In Polish: Perspektywy rozwoju transportu intermodalnego $\mathrm{w}$ Polsce], Administracja i Zarządzanie 34(107): 257-260.

Rosa, G. 2013. Conditions of Development of Intermodal Transport in Poland [In Polish: Uwarunkowania rozwoju transportu intermodalnego w Polsce], Problemy Transportu i Logistyki 22: 281-294.

MTBGM. 2013. Transport development strategy until 2020 (with a perspective until 2030) [In Polish: Strategia rozwoju tranasportu do 2020 roku (z perspektywą do 2030 roku)]. Ministerstwo Transport, Budownictwa i Gospodarki Morskiej. Available from Internet: <https:// www.gov.pl/documents/905843/1047987/Strategia_ Rozwoju_Transportu_do_2020_roku.pdf/ead3114aaac7-3cdd-c71d-7f88267ce596>.

Saunders, M.; Lewis, P.; Thornhill, A. 2016. Research methods for business students. Pearson, England. 108p.

Stawiński, M. 2016. Intermodal transport. Road transport vs. rail. Analysis of the Office of Rail Transport [in Polish: Przewozy intermodalne. Transport drogowy vs. kolej. Analiza Urzedu Transportu Kolejowego], 18p. Available from Internet: <https://www.utk.gov.pl/ $\mathrm{pl} /$ raporty-i-analizy/analizy-i-monitoring/analizy-iopracowania/7458,Przewozy-intermodalne-transportdrogowy-vs-kolej.html>.

Stokłosa, J.; Cisowski, T.; Erd, A. 2014. Intermodal terminals - as elements encourage development of intermodal transport chains [In Polish: Terminale przeladunkowe jako element infrastruktury sprzyjajacej rozwojowi lańcuchow transportu intermodalnego], Logistyka 2014(3): 5991-5999.

Szepietowska, E.; Baran, J. 2012. Prospects for the development of intermodal transport in Poland [In Polish: Perspektywy rozwoju transportu intermodalnego w Polsce], Logistyka 2012(6): 603-612.

UTK. 2012. Railway transport market analysis. Railway Transport Office [In Polish: Analiza Rynku Kolejowych przewozów. Urząd Transportu Kolejowego]. Available from Internet: <https://utk.gov.pl/download/1/3307/ Analizarynkukolejowychprzewozowintermodalnych. pdf $>$.

UTK. 2013. Barriers to the development of the intermodal transport market - solutions and tangible benefits. Railway Transport Office [in Polish:Bariery rozwoju rynku przewozów intermodalnych rozwiązania i wymierne korzyści. Urząd Transportu Kolejowego]. Available from Internet: <https://utk.gov. pl/pl/aktualnosci/2659, Raport-quotBariery-rozwojurynku-przewozow-intermodalnych-rozwiazania-iwymierne.html>.

UTK. 2016a. Analysis of intermodal rail transport in Poland. Railway Transport Office [In Polish:Analiza kolejowych przewozów intermodalnych w Polsce. Urząd Transportu Kolejowego]. Available from Internet: <https://utk.gov.pl/pl/aktualnosci/6936,Analizakolejowych-przewozow-intermodalnych-w-Polsce. html>. 
UTK. 2016b. Assessment of the functioning of the rail transport market and the state of rail traffic safety in 2015. Railway Transport Office [In Polish: Ocena funkcjonowania rynku transportu kolejowego i stanu bezpieczeństwa ruchu kolejowego w 2015 roku. Urząd Transportu Kolejowego]. Available from Internet: <https://www.utk.gov.pl/ftp/filmy/UTK_raport_2015 PL.pdf $>$.

UTK. 2018a. Intermodal transport in 2012. Railway Transport Office [In Polish: Przewozy intermodalne w 2012r. Urząd Transportu Kolejowego]. Available from Internet: <https://utk.gov.pl/pl/raporty-i-analizy/ analizy-i-monitoring/statystyka-przewozow-to/danearchiwalne/11916,Przewozy-intermodalne-w-2012-r. html>.

UTK. 2018b. Intermodal transport in 2013. Railway Transport Office [In Polish: Przewozy intermodalne w 2013r. Urząd Transportu Kolejowego]. Available from Internet: <https://www utk.gov.pl/pl/raporty-ianalizy/analizy-i-monitoring/statystyka-przewozow-to/ dane-archiwalne/12431, Przewozy-intermodalne-w2013-r.html>.

UTK. 2018c. Intermodal transport in 2014. Railway Transport Office [In Polish: Przewozy intermodalne w 2014r. Urząd Transportu Kolejowego]. Available from Internet: <https://www.utk.gov.pl/pl/raporty-ianalizy/analizy-i-monitoring/statystyka-przewozow-to/ dane-archiwalne/11909, Przewozy-intermodalne-w2014-r.html>.
UTK. 2018d. Intermodal transport in 2015. Railway Transport Office [In Polish: Przewozy intermodalne w 2015r. Urząd Transportu Kolejowego]. Available from Internet: <https://www.utk.gov.pl/pl/raporty-ianalizy/analizy-i-monitoring/statystyka-przewozow-to/ dane-archiwalne/11907,Przewozy-intermodalne-w2015-r.html>.

UTK. 2018e. Intermodal transport in 2016. Railway Transport Office [In Polish: Przewozy intermodalne w 2016r. Urząd Transportu Kolejowego]. Available from Internet: <https://utk.gov.pl/pl/raporty-i-analizy/ analizy-i-monitoring/statystyka-przewozow-to/danearchiwalne/13033,Przewozy-intermodalne-w-2016-r. html>.

Wagner, N. 2014. Intermodal transport in Europeopportunities through innovation, LogForum 10(4): 371-382.

Wiśnicki, B.; Milewski, D.; Chybowski, L.; Helczynski, I. 2017. The Concept of the Development of Intermodal Transport Network Illustrated by Polish Market, Naše More 64(1): 33-37. 